\title{
FINANCIAL ASPECTS OF CURRENT ASSETS MANAGEMENT IN SERBIAN ECONOMY
}

\author{
Jugoslav Aničić, ${ }^{1}$ Nataša Simić, ${ }^{2}$ Vesna Petrović, ${ }^{3}$ Dušan Aničić, ${ }^{4}$ \\ 1,2,3 "Union-Nikola Tesla University", Faculty of Entrepreneurial Business, Serbia, \\ ${ }^{4}$ DSN Consalting, Belgrade, Serbia \\ ajugoslav@yahoo.com; nsimic68@gmail.com; al.petrovicpn@gmail.com; anicic.dusan@yahoo.com
}

\section{Professional Paper doi:10.5937/jouproman5-13442}

\begin{abstract}
Efficient current assets management should provide optimum level of company's net current assets as interrelation between current assets and short-term liabilities. The companies whose short-term liabilities are not proportionate to cashable current assets face the problem of insolvency and all negative consequences caused by insolvency. Rate of return to total assets measures how good is the management's use of the company property for the purpose of creating operating profit, regardless of the fact how these assets are financed. Serbian economy is burdened by insolvency and significant indebtedness under unfavorable loan terms, so adequate attention has to be dedicated to the matters of the structure of operating property and its financing in order to improve competitiveness and efficiency of business.
\end{abstract}

Key words: working capital, asset management, economy, Serbia

\section{Introduction}

Company's working capital is mostly comprised of inventories, receivables and cash elements, so working assets are much more liquid than fixed assets, together with which they comprise company's operating capital. On the other hand, investments into working assets provide lower return than investments into fixed assets, so the matters of the capital structure and the manner of its financing are highly important in terms of financial and capital position of the company. Relationship between profitability and risks which are conditioned by the scope of net working assets with which the company operates depend from working capital management.
Efficiency of capital management is directly related to liquidity, solvency and profitability of the company and, due to that, the analysis of the turnover is in the mid of the ratio of the analysis of financial statements.

The achieved results from operations of companies in 2015 and previous years show that the period of transitional recession left negative consequences to structure of working capital, as well as the structure of its financing. Serbian company is characterized by the lack of own capital, insolvency and indebtedness during the complete transitional period. Under such conditions, the economy is forced to use banking loans under very unfavorable conditions, with high interest rate, inadequate maturity of loans and limitations in company's business policy. The companies largely compensate the lack of capital for financing of current operations by means of irregular payment of trade receivables, which causes increase of chained insolvency in company.

The objective of this paper is to emphasize the significance which working assets have in company's operations, the influence and influence which the working capital management policy has on liquidity and profitability operations, as well as to point out the necessary improvements in company structuring and more efficient policy of their use. 


\section{Role and significance of working capital in the company}

The total capital which a company has at its disposal, depending from its characteristics, is divided into two groups, namely:

1. Fixed assets include: intangible assets, property, plant and equipment, biological assets, longterm financial placements and longterm receivables;

2. Working assets include: inventories, receivables based on sales and other receivables, longterm financial placements, cash equivalents and cash, entry VAT and prepayments and accrued income

Working assets represent a part of operating assets which, as a rule, transfer their value at once to the product of the new value in use (Rodić, et al, 2015). Working assets are those assets which are, within one reproduction cycle, transformed from initial form - money $(\mathrm{N})$ - into final form - money (N1). The length of the reproduction cycle mostly depends from the length of the technological process. In most cases, it lasts less than a year, and since the other stages of the reproduction cycle (purchase stage and execution stage) are much shorter, it can be concluded that transformation of working assets from initial into final form is performed within one year.

Some of the most important characteristics which differentiate working assets from fixed assets of the company are the following (Aragon, 1989, Gitman, 1991,):

- Working assets are more liquid than fixed assets;
- Investments into working assets provide lower income than the investments into fixed assets;

- Financing from short-term sources bears higher risk degree than financing from long-term sources;

- Funds from short-term sources can be obtained much faster than the funds from long-term sources and financing from short-term sources is more flexible in comparison with financing from long-term sources.

Fixed assets will be transformed to cash by means of depreciation or sale at much slower pace, so the working assets are more liquid, and the higher the share of working assets in total operating assets of the company is, the smaller is the risk from company's insolvency and vice versa (Ivanišević, 2008). As opposed to liquidity, increase of ratio of working assets in relation to total operating assets, i.e. increase of share of working assets in total assets, influences decrease of total rentability, because investments into working assets, as a rule, provide lower income rate than investments into fixed assets.

Pursuant to paragraph 4.5. of the International Financial Reporting Standards for small and medium companies, the entity should classify capital as working capital if (Group of authors, 2014.):

- It is expected that it will be executed, or if it is kept for sale or consumption, during regular business cycle of the entity;

- It is kept primarily for trading purpose;

- It is expected that it will be executed within twelve months from the statement date; or 
- If it is cash or cash equivalent, except if its exchange or use for settlement of liabilities is limited during at least twelve months from the reporting date.

Needs for working capital vary depending from the company's activity, and they depend from production dynamics, conditions for raw material supply, dynamics and amount of sale, scope and dynamics of services and other. Adequate management of working assets should provide optimal level of net working assets of the company as an interrelation between working assets and short-term liabilities. Ratio of profitability and risks conditioned by the scope of net working assets with which the company operates depends from working capital management. It should also contribute to choice of the most favorable strategy for financing working assets.

Each individual item of working capital has its own specificities and requires special analysis by adequate company services. For example, the company must strive towards optimal level of inventories which enable undisturbed performance of activity with the lowest costs. On the other hand, the appropriate level of inventories is always necessary for normal operation of the company, but inventories cause costs of keeping, adjustment and holding and bear the risk from statute of limitations and loss of value.

The key aspects in terms of receivables management relate to the policy of credit financing of the buyers, loan conditions and policy for collection of receivables, which are subject to very fast changes due to sharp competition on the market. Efficient management of cash and securities should secure balance between profitability and liquidity in sense that the surplus cash is profitably invested without endangering liquidity. Sudden oscillations in net cash flow can be most depreciated by sale and purchase of short-term securities.

The companies in which short-term liabilities are disproportionate to cashable working capital encounter insolvency problem and all of the negative consequences caused by that problem. Due to the above-mentioned, timely reaction is necessary in order to overcome insolvency, and the companies have numerous options for doing that, such as pre-structuring of assets, increase of asset turnover and extension of deadlines for payment of liabilities. Besides the above-mentioned, additional cash assets can be achieved from sale of unused fixed assets, sale of raw materials which exceed minimum inventories, lowering prices of finished products and other measures.

In order for the liquidity policy to be properly managed, work of all company functions needs to be harmonized (financial, purchase and sale, investment), controlled indebtedness, optimum level of inventories, appropriate level of liquid reserves, plan for cash inflow and outflow, as well as choice of method of financing of working assets. In order to achieve optimum level of liquidity, the company has to know well and control the length of its operating and cash cycle. Business cycle represents average time which passes from the moment of purchase of materials until the moment when receivables are collected from the buyers, and cash cycle is the average tome which passes from the time when the cash is separated (payment of liabilities to suppliers and worker earnings) until cash is received, i.e. collection of receivables from buyers.

Basic objective of the company in terms of liquidity is the shortening of the cash cycle, i.e. increase of coefficient of cash turnover. 
The higher the coefficient of cash turnover, less cash is used in operations and costs related to cash keeping are decreased. These effects can be achieved by means of strategies for cash management, such as faster collection of receivables from the buyers, extension of deadline for payment of liabilities to suppliers and other shortterm liabilities, as well as more efficient management of inventories.

Financial management is significantly more complex in international business environment due to action of the following factors (Besley, Brigham, 2015.): different currency denomination, differences in economic and legal environment, language and cultural differences, role of the government and political risk. Business decisions are more difficult to adapt, i.e. change, when the rules, regulations and business culture significantly differ in various business environments.

\section{Economic results and efficiency of capital management}

Liquidity of a company is short-term capacity of the company to create cash for the sakes of working capital and indirect repayment of debts. Solvency is related to long-term capacity of the company to create cash from internal or external sources in order to settle the needs of capacities of its plants, incite development and repay debts when they are due (Kothari, Barone, 2012). Total profitability of the company is the product of activity indicators and profitability indicators. Income on total assets (capital) is the relationship between EBIT and total assets. EBIT represents the amount obtained after deducting total operating costs from total income, before deduction of interest and tax costs. Rate of income on total assets measures how well the management uses all company capital in order to create business profit, regardless of the fact how these funds are financed.
The management manages the company in a complex economic environment based on parameters which measure the achieved results and compare them with the set objectives, whereby the financial parameters such as ROE (Return on Equity), ROCE (Return on Capital Employed), DuPont, and other, are used. Basic flaw of these parameters is that they are exclusively based on financial data from previous periods, whereas the factors which affect the future of the company are not included in the reports on company's operations. In order for the company management based on long-term objectives to be successful, the parameters must include indicators which do not reflect only the past, but also provide information about the future development of the company (Aničić, et, al. 2016).

The efficiency of capital management is directly related to liquidity, solvency and profitability of the company and that is why the analysis of turnover occupies the central position in the ratio of analysis of financial statements (Stevanović, et.al. 2009). Turnover of total capital and owner's capital represents a multiplier of profitability, which is why the increase of turnover, i.e. increase of the capacity to create income which includes increased share of profit, results in increase of the company's profitability. Turnover is powerful management leverage for shaping of company's performances and for evaluation and projection of the status of the company's long-term and short-term financial security.

The above-mentioned, together with numerous other indicators of business and success in use of company's property in Serbian economy, show that incorrect economic policy during the transitional period, as well as global financial crisis, left significant consequences on (non)successfulness of Serbian economy. 
It is indisputable that the economy will need a lot time to reach the level of medium developed regional countries, regardless of the fact that Serbian economy was more advanced a couple of decades ago.

Presented results of companies' operations in 2015 show signs of economic recovery in Serbia in comparison with the previous year. The economy, observed as a whole, has achieved positive net financial result in the amount of 143.790 million Dinars, whereas net loss in the amount of 132.618 million Dinars (Table 1) was recorded in 2014. However, the information that 27.521 companies operated with loss indicates serious weaknesses of the economy in terms of rentability of operations and efficient use of operating capital.

Table 1: Results of operations of companies in 2014 and 2015

\begin{tabular}{|l|c|c|l|c|}
\hline \multirow{2}{*}{\multicolumn{1}{|c|}{ DESCRIPTION }} & \multicolumn{2}{c|}{2015} & \multicolumn{2}{c|}{2014} \\
\cline { 2 - 5 } & $\begin{array}{l}\text { Amount (in } \\
\text { million RSD) }\end{array}$ & $\begin{array}{l}\text { Number of } \\
\text { companies }\end{array}$ & $\begin{array}{l}\text { Amount (in } \\
\text { million RSD) }\end{array}$ & $\begin{array}{l}\text { Number of } \\
\text { companies }\end{array}$ \\
\hline 1. Net profit & 466.661 & 54.475 & 407.209 & 53.090 \\
\hline 2. Net loss & 322.871 & 27.521 & 539.827 & 28.894 \\
\hline Net financial result (1-2) & 143.790 & - & -132.618 & - \\
\hline
\end{tabular}

Source: Business Registers Agency 2016, Communication on economic operations in the Republic of Serbia in 2015

In 2015, the economy presented significantly better results measured with profitability indicators - rate of income on total assets and rate of income on own equity after taxation. Although both rates are low (respectively, 2,2 and 3,6), significant progress was made in comparison with the previous year when the rate of income on own equity was negative (Table 2). Since the rate of income on own equity is higher than the income on total assets, the companies, observed totally, managed to financed costs of borrowed equity from achieved profit, which proves that its use in operations was justified. This also decreases the risk from payment of interests which is a significant flaw of the economy during the complete transitional period.

The rate of net profit was 1,7 and it represents a significant progress in comparison with the previous year, when it was negative and amounted to 1,6. This data indicates that the economy was less encumbered by financial expenses (interests, differences in exchange rates) in comparison with the previous year, because the rate of operating profit has been slightly increased (far less than the rate of net profit which is obtained after calculation of financial expenses and taxation). 
Table 2: Profitability indicators at the level of the economy in 2014 and 2015

\begin{tabular}{|l|c|c|}
\hline \multicolumn{1}{|c|}{ DESCRIPTION } & 3,6 & 2014 \\
\hline 1. Rate of income on own equity (after taxation) & 2,2 & 1,1 \\
\hline 2. Rte of income on total assets (after taxation) & 4,8 & 4,5 \\
\hline 3. Rate of operating profit & 1,7 & $-1,6$ \\
\hline 4. Rate of net profit & \\
\hline
\end{tabular}

Source: Business Registers Agency 2016, Communication on economic operations in the Republic of Serbia in 2015

Higher rate of income on equity represents support to the financial frame of a company which is growing and being developed, and at the level of the total economy, it incites investments, growth of gross domestic product, employment, higher tax income for the state etc.

\section{Structure of operating property and sources of financing}

The results achieved from operation of companies in 2015 and the previous years indicate that the period of transitional recession left negative consequences on structure of operating property, as well as on the structure of its financing. According to the indicators in Table 3, we can see that the operating capital in 2015 had higher growth than the fixed capital $(3,0: 1,8)$. Total operating capital in 2015 amounts to 5.121.560 million Dinars and it is mostly comprised from receivables based on sale, which amount to $1,750.798$ million Dinars, according to the Communication issued by the Business Registers Agency. At the same time, the inventories recorded increase of $8,1 \%$ and cash equivalents and cash increased for $12,8 \%$. Share of working capital in the total capital of companies is at the approximate level of $40 \%$.

Table 3: Structure of operating capital of companies in 2015 and 2014 in million RSD

\begin{tabular}{|l|c|c|c|}
\hline \multicolumn{1}{|c}{ DESCRIPTION } & 2015 & 2014 & Index \\
\hline 1. Subscribed and unpaid equity & 21.088 & 23.137 & 91,1 \\
\hline 2. Fixed capital & 7.650 .388 & 7.513 .958 & 101,8 \\
\hline 3. Deferred tax assets & 39.952 & 42.223 & 94,6 \\
\hline 4. Working capital & 5.121 .560 & 4.973 .181 & 103,0 \\
\hline 5. Total assets = Operating capital & 12.832 .988 & 12.552 .499 & 102,2 \\
\hline
\end{tabular}

Source: Business Registers Agency 2016, Communication on economic operations in the Republic of Serbia in 2015 
The lack of own equity in Serbian economy is also indicated by the relationship between equity and total liabilities of companies in 2015, because the liabilities are stated in the amount of 8.306.033 million RSD and significantly higher than the equity, which amounts to 6,069.475 million RSD (Table 4). Although the equity increased faster than the growth of total debt $(3,9 \%$ to $3,0 \%)$, own financing sources, due to stated loss, remained almost unchanged in relation to the previous year. Due to the abovementioned, the ratio of own equity mildly decreased when compared with the previous year, but the indebtedness of national economy significantly increased, which is also indicated by the degree of total indebtedness, which increased from 1,80 in 2014 to 1,84 in 2015. The companies largely compensate the lack of equity for financing current operation with irregular payment of trade liabilities, which causes increase of chain insolvency in the economy.

Solvency of national economy was disturbed during the transitional period, so only mild improvement was stated in 2015 in comparison with the previous period. At the level of the economy, the debt structure is still unfavorable in sense that short-ter debts significantly exceed long-term debts (5.729.888 to 2.404.228 million). Shortterm credit financing of the economy has, according to the information of the
Business Registers Agency, increased for $4 \%$ and the scope of short-term loans which the companies used reached the amount of 1,856.716 million RSD. Decrease of interest rate in global proportions which, with delay, also reflected on our financial market, represents a favorable circumstance for the economy. However, interest rates are still significantly higher than the rate of income or net profit for large part of our economy. Also, a stable foreign exchange rate is highly important for economic operations because loan debts are for the most part indexed in a foreign currency.

Bearing in mind the presented results of the Serbian economy, it can be concluded that it is still dominated by inadequate capital financing, which is largely a consequence of recession which occurred during the previous period. Due to disturbance of long-term financial balance, the practice of significantly financing the fixed capital from short-term equity was continued, so a high level of negative net working equity of companies was also kept and amounted to 739.896 million Dinars in 2015. Shortage of long-term sources also negatively reflects on liquidity, so the general liquidity ratio is $0,87(0,84$ in 2014), and the current liquidity ratio is 0,60 (0,58 in 2014). As a reminder, desirable sizes of these indicators are 2, 0 for general liquidity and 1,0 for current liquidity. 
Table 4: Structure of sources of financing of companies in 2015 and 2014 in million RSD

\begin{tabular}{|l|c|c|c|}
\hline \multicolumn{1}{|c}{ DESCRIPTION } & 2015 & 2014 & Index \\
\hline 1. Equity & 6.069 .475 & 5.844 .060 & 103,9 \\
\hline 2. Long-term provisions and liabilities & 2.404 .228 & 2.305 .771 & 104,3 \\
\hline 3. Deferred tax liabilities & 171.917 & 166.383 & 103,3 \\
\hline 4. Short-term liabilities & 5.729 .888 & 5.589 .063 & 102,5 \\
\hline 5. Loss above capital & 1.542 .520 & 1.352 .778 & 114.0 \\
\hline 6. Total liabilities & 12.832 .988 & 12.552 .499 & 102,2 \\
\hline
\end{tabular}

Source: Business Registers Agency 2016, Communication on economic operations in the Republic of Serbia in 2015

\section{Conclusion}

The matters related to the structure of operating capital and the method of its financing are highly important for financial and economic position of companies. Efficient management of working capital significantly contributes to profitability and lowers the risk from insolvency of the company, so the analysis of turnover of constituent parts, as well as the total capital, occupies the central position in the ratio analysis of financial statement. On the other hand, investments into working assets provide lower income than investments into fixed assets, so the issues related to efficiency of working assets are unjustifiably neglected. Due to disorder of long-term financial balance in Serbian economy, the practice of largely financing fixed assets from short-term equity has been continued, so high level of negative net working equity of the companies also remained.

The period of transitional recession left negative consequences on structure of operating capital, as well as structure of its financing in Serbian economy. During the whole transitional period, the economy is accompanied by lack of own equity, insolvency and indebtedness, so the economy is forced to use bank loans under very unfavorable terms, starting from high interest rate, over inadequate loan maturity and limitations in management of company business policy. Faced with lack of capital for financing current operations, the companies extend settlement of trade liabilities, which causes increase of chain insolvency in the economy. In such environment, the rates of income on used capital are extremely low, which indicates low competence of the company on the international market.

\section{References}

[1] Source: Business Registers Agency 2016, Communication on economic operations in the Republic of Serbia in 2015, Belgrade

[2] Aragon, G.A., (1989) Financial management, Allyn and Bacon, Boston

[3] Aničić, J., Petrović, V., Aničić, D., (2016): Finansijska i marketing perspektiva preduzeća prema konceptu uskladjene liste, JPMNT, Volume 4, Issue 1, str. 1016. 
(JPMNT) Journal of Process Management - New Technologies, International

Vol. 5, No 2, 2017.

[4] Besley, S., Brigham, E., (2015), Corporate finance, DATA STATUS, Beograd

[5] Gitman, L.J., (1991) Principles of Managerial Finance, Harper Collins, New York

[6] Grupa autora (2014), Priručnik za primenu kontnog okvira za srednja, mala i mikro pravna lica i preduzetnike, Privredni savetnik, Beograd

[7] Ivanišević, M., (2008) Poslovne finansije, Ekonomski fakultet, Beograd
[8] Kothari, J., Barone, E., (2012) Finansijsko računovodstvo - medjunarodni pristup, DATA STATUS, Beograd.

[9] Rodić, J., Andrić, M., Vukelić, G., Vuković, B., (2015) „Analiza finansijskih izveštaja" Beograd

[10] Stevanović, N., Malinić, D., Milićević, D., (2009) Upravljačko računovodstvo, Ekonomski fakultet, Beograd 